\section{Substitution of a Soilless Medium with Yard Waste Compost for Basil Transplant Production}

\author{
Courtney D. DeKalb ${ }^{1,4}$, Brian A. Kahn ${ }^{1,5,7}$, Bruce L. Dunn ${ }^{1,6}$, \\ Mark E. Payton ${ }^{2,5}$, and Allen V. Barker ${ }^{3,5}$
}

AdDITIONAL INDEX wORDs. Ocimum basilicum, alternative substrate, organic wastes, peat, sulfur

SUMMARY. Four experiments were conducted under greenhouse conditions in Oklahoma. Pelleted 'Genovese' basil (Ocimum basilicum) seeds were sown in polystyrene flats with six different blends of a peat-lite mix (PLO) and yard waste compost [YWC (this batch designated C0)] in 2012 for the first two experiments. The proportions by volume of PL0:C0 included 100\%:0\%, 80\%:20\%, 60\%:40\%, 40\%:60\%, 20\%:80\%, and 0\%:100\%. Seedling establishment was unaffected consistently, but there was a distinct decline in seedling height and dry weight between $100 \%$ PLO and 80\% PL0:20\% C0, followed by smaller decreases as the percentage of compost increased in the blends. A third experiment was conducted in 2013 with a different batch of peat-lite (PL1) after the compost had aged 17 months (now designated C1). Treatments were 100\% PL1, 80\% PLl:20\% Cl, and 80\% PL1:20\% Cl mixed with sulfur (S) at 1, 2, or $3 \mathrm{lb} /$ yard $^{3}$ of blend to acidify the media. The $100 \%$ PLI treatment delayed seedling emergence and suppressed height and dry weight relative to seedlings grown in 80\% PL1:20\% Cl blends. The PLl subsequently was found to have been produced in 2010 , and the wetting agent had apparently degraded. The aged 2012 compost (C1) was not inhibitory to basil seedling growth when blended at $20 \%$ with the PLl, and in fact restored utility to the PL1. The carbon:nitrogen ratio of the original 2012 compost (C0) was 10.8:1, suggesting stability. It appeared that the main reason the $\mathrm{C} 0$ compost was inhibitory was that mineralization was slow or immobilization occurred, causing a lack of plant-available nitrogen, especially nitrate. Treatments with $S$ lowered $\mathrm{pH}$ of the media, but there were no differences in basil seedling growth between the unamended $80 \% \mathrm{PLI}: 20 \% \mathrm{Cl}$ blend and blends with added S. A fourth experiment compared three peat-lite media: PLl; a batch of the same medium as PLl that was produced in 2013 (PL2); and a different medium also produced in 2013 (PL3). Peat-lite media were either used unblended, or blended with $20 \% \mathrm{Cl}$ or $20 \% \mathrm{C} 2$ (a fresh batch of YWC obtained from the same facility that had produced the original C0). The unamended PLl was again inhibitory to basil seedling establishment and development. The two "fresh" peat-lite media (PL2 and PL3) were not inhibitory and were similar to each other in performance. A blend of $80 \%$ PL2 or $80 \%$ PL3 with $20 \%$ compost produced similar (C2) or somewhat better (C1) results than were obtained with the unamended peat. We conclude that a blend of $80 \%$ peat-lite medium and $20 \%$ YWC can be used to produce basil transplants. However, producers must consider the quality of the peat-lite medium and the compost based on the age and composition of the components.

S oilless, peatmoss-based growing media are used commonly in vegetable transplant production (Sterrett, 2001). Peatmoss-based media give consistent and reliable results in the horticulture industry (Boodley and Sheldrake, 1982), but peatmoss is declining in availability and increasing in price (Sterrett, 2001). Compost has been suggested as a possible substitute to reduce both the environmental impact of harvesting peatmoss and costs for growers (Bugbee and Frink, 1989; Sterrett, 2001; Treadwell et al., 2007). Compost is considered a safe and environmentally responsible

\begin{tabular}{llll}
\hline $\begin{array}{l}\text { Units } \\
\text { To convert U.S. to SI, } \\
\text { multiply by }\end{array}$ & U.S. unit & SI unit & $\begin{array}{l}\text { To convert SI to U.S., } \\
\text { multiply by }\end{array}$ \\
\hline 29.5735 & $\mathrm{fl} \mathrm{oz}$ & $\mathrm{mL}$ & 0.0338 \\
0.0283 & $\mathrm{ft}^{3}$ & $\mathrm{~m}^{3}$ & 35.3147 \\
3.7854 & $\mathrm{gal}$ & $\mathrm{L}$ & 0.2642 \\
2.54 & inch $(\mathrm{es})$ & $\mathrm{cm}$ & 0.3937 \\
25.4 & inch $(\mathrm{es})$ & $\mathrm{mm}$ & 0.0394 \\
453.5924 & $\mathrm{lb}$ & $\mathrm{g}$ & 0.0022 \\
0.0160 & $\mathrm{lb} / \mathrm{ft}^{3}$ & $\mathrm{~g} \cdot \mathrm{cm}^{-3}$ & 62.4274 \\
0.5933 & $\mathrm{lb} / \mathrm{yard} \mathrm{d}^{3}$ & $\mathrm{~kg} \cdot \mathrm{m}^{-3}$ & 1.6856 \\
1 & $\mathrm{mmh} / \mathrm{cm}$ & $\mathrm{dS} \cdot \mathrm{m}^{-1}$ & 1 \\
28.3495 & $\mathrm{oz}$ & $\mathrm{g}$ & 0.0353 \\
28,350 & $\mathrm{oz}$ & $\mathrm{mg}$ & $3.5274 \times 10^{-5}$ \\
1 & $\mathrm{ppm}$ & $\mathrm{mg} \cdot \mathrm{kg}^{-1}$ & 1 \\
$\left({ }^{\circ} \mathrm{F}-32\right) \div 1.8$ & ${ }^{\circ} \mathrm{F}$ & ${ }^{\circ} \mathrm{C}$ & $\left({ }^{\circ} \mathrm{C} \times 1.8\right)+32$ \\
& & & \\
\hline
\end{tabular}

product, but it can vary in nutrient content, other chemical properties, and biological properties (Raviv, 2005).

The use of YWC has become increasingly desirable in the past few years. Yard waste compost includes grass clippings, leaves from trees and shrubs, woody branches, and other materials that are the result of yard trimmings (Ozores-Hampton et al., 1999). Facilities designed to process YWC have become more popular across the United States (Goldstein, 2001). Several studies have examined the use of YWC as a potential substitute for peat-lite mixes in containerized plant production (Burger et al., 1997; Hartz et al., 1996; Ozores-Hampton et al., 1999; Spiers and Fietje, 2000).

Basil has been a popular choice for greenhouse growers over the past few decades because of its high dollar value. While some studies have been conducted on compost use for herb production (De Lucia et al., 2013; Herrera et al., 1997; O'Brien and Barker, 1996), only a few have involved compost use for basil production. Fresh weights of basil transplants grown in a manure-wheat straw (Triticum aestivum) compost were higher than those of transplants grown in peat, and the compost suppressed the development of fusarium wilt (incited by Fusarium oxysporum f. sp. basilici) in the transplants (Reuveni et al., 2002). Container-grown basil plants grew well in a mixture of soil and $20 \%$ source-separated municipal solid waste compost in a study by Zheljazkov and Warman (2004). Succop and Newman (2004) demonstrated that, with appropriate hydroponic cultural practices, basil could be grown in a greenhouse using a commercial peat-perlite compost (blend of wood waste and poultry 
manure) medium in a polyethylene bag. Pitchay and Diaz-Perez (2008) successfully produced basil transplants in blends of coir and up to $40 \%$ by volume of a compost of unspecified feedstock. We found no studies that demonstrated production of basil transplants using YWC. Therefore, our objective was to determine the feasibility of using YWC as a substitute for, or amendment to, peat-lite growing media for basil transplant production.

\section{Materials and methods}

All experiments were conducted under natural photoperiods in singlelayer polycarbonate greenhouses at Oklahoma State University in Stillwater.

Expts. 1 AND 2. Yard waste compost was generated by the Norman Composting Facility in Norman, OK, and released as "finished." Feedstocks were leaves, grass clippings, and limbs $\leq 2$ inches in diameter, and composting was by the turned windrow method. Compost (designated C0) was obtained on 23 Mar. 2012 and screened to 0.5 inch before use. Experimental media were prepared individually in 10-L batches on 27 Mar. 2012. The control was $100 \%$ peat-lite (PL0) (Redi-Earth, averaging 50\% to $60 \%$ Canadian sphagnum peat, plus horticultural grade vermiculite and dolomitic limestone; Sun Gro Horticulture, Agawam, MA). Treatments were PLO mixed with the compost at 80\%:20\%, 60\%:40\%, 40\%:60\%, and $20 \%: 80 \%$ by volume, and $100 \%$ compost.

\footnotetext{
Approved for publication by the Director, Oklahoma Agricultural Experiment Station. This research was supported in part under project $\mathrm{H}-2026$. The information given in this publication is for educational purposes only.

Mention of a trademark, proprietary product, or vendor does not constitute a guarantee or warranty of the product, nor does it imply approval or disapproval to the exclusion of other products or vendors that may also be suitable.

${ }^{1}$ Department of Horticulture and Landscape Architecture, 358 Agricultural Hall, Oklahoma State University, Stillwater, OK 74078-6027

${ }^{2}$ Department of Statistics, 301 MSCS Building, Oklahoma State University, Stillwater, OK 74078-1056

${ }^{3}$ Stockbridge School of Agriculture, 202 Bowditch Hall, University of Massachusetts, Amherst, MA 01003-9294

${ }^{4}$ Wentz Undergraduate Research Scholar

${ }^{5}$ Professor

${ }^{6}$ Associate Professor

${ }^{7}$ Corresponding author. E-mail: brian.kahn@okstate. edu.
}

The two experiments were set up in parallel $3 \mathrm{~d}$ apart, with the second designed to repeat the first. Each experiment used 12 polystyrene flats with inverted pyramid cells (cell size $1 \times 1 \times 3$ inches deep, 200 cells per flat; Speedling, Ruskin, FL). Duct tape was placed down the middle two columns of the flats to allow two media treatments per flat. The experiments were arranged in randomized complete block designs with four replications. Edge cells were not used for data, leaving 56 data cells per treatment per replication. Filled flats were watered to saturation. After $2 \mathrm{~d}$ (29 Mar. and 1 Apr.), two pelleted 'Genovese' basil seeds were planted about $7 \mathrm{~mm}$ deep in the medium in each cell. Additional amounts of the appropriate medium were spread over the top of the cells after planting as needed to ensure all seeds were planted at the same depth. Flats then were watered and placed in the greenhouse, where they continued to be watered daily. Temperature set points were $72 / 65^{\circ} \mathrm{F}$ (day/night), but daytime temperatures sometimes were higher.

Emergence was recorded every morning and every evening for $12 \mathrm{~d}$ (monitoring periods were 1 to 12 April for Expt. 1 and 6 to 17 April for Expt. 2). As each newly emerged seedling was counted, a toothpick was placed in its flat cell so that it would not be counted twice. Seedlings were thinned to the one strongest plant in each cell on 19 April for Expt. 1 and 24 April for Expt. 2, and a postthinning stand count was done to determine how many flat cells in the data areas were empty. Seedlings subsequently were fertilized twice in each experiment using $1 \mathrm{oz}$ of soluble fertilizer $(20 \mathrm{~N}-8.7 \mathrm{P}-16.6 \mathrm{~K})$ in $2 \mathrm{gal}$ of water each time. Dates of fertilization were 22 April and 2 May for Expt. 1, and 27 April and 6 May for Expt. 2.

Plants were harvested on 12 May in Expt. 1 and on 17 May in Expt. 2. The heights of 10 randomly chosen seedlings per treatment per replication were taken (total of 240 seedlings per experiment). Seedling stems were cut at the medium level and measured from there to the apical bud. After heights were taken, fresh weights were recorded for use in future calculation of percent dry weight. Seedlings then were placed into individual coin envelopes to be dried at $70{ }^{\circ} \mathrm{C}$ for $7 \mathrm{~d}$, after which dry weights were recorded.

ExPT. 3. It was not possible to continue the study immediately after the conclusion of Expts. 1 and 2. In the interim, left-over compost from the 2012 experiments was stored at room temperature in non-air-tight plastic trash cans.

Experimental media were prepared individually in $10-\mathrm{L}$ batches on 8 Sept. 2013. The control was 100\% peat-lite (PLl) (Redi-Earth, but not the same batch as was used in 2012). An 80\% PLl:20\% compost baseline treatment was created by mixing the PLl with left-over compost from the 2012 experiments (designated $\mathrm{Cl}$ ). Additional treatments were the $80 \%: 20 \%$ blend mixed with 1,2 , or $3 \mathrm{lb}$ sulfur per cubic yard of blend. We determined that the blend weighed $7600 \mathrm{~g} / \mathrm{ft}^{3}$. Therefore, the target treatments were achieved by adding $1.0,2.0$, or $3.0 \mathrm{~g}$ wettable $S$ to $1 \mathrm{lb}$ of the blend and mixing thoroughly.

Ten polystyrene flats were prepared as described for Expts. 1 and 2. The experiment was arranged in a randomized complete block design with four replications. Flats were filled and watered to saturation on 8 Sept. Pelleted 'Genovese' basil seeds were planted the next day following the procedures described for Expts. 1 and 2. Flats were watered after seeding and placed in the greenhouse, where they continued to be watered daily. Temperature set points were $72 / 65^{\circ} \mathrm{F}$ (day/night), but daytime temperatures often approached $90{ }^{\circ} \mathrm{F}$ on sunny days.

Media $\mathrm{pH}$ values were tested using 1 medium: 2 water $(\mathrm{v} / \mathrm{v})$ extraction. A $150-\mathrm{mL}$ sample of medium was mixed with $300 \mathrm{~mL}$ of deionized water in a $500 \mathrm{~mL}$ beaker. The beaker was placed on a stirring plate at a low setting for $30 \mathrm{~min}$. The $\mathrm{pH}$ then was measured using a pH meter (2100; Oakton Instruments, Vernon Hills, IL). Baseline $\mathrm{pH}$ values for $100 \%$ PLl, 100\% Cl, and the 80\% PLl:20\% $\mathrm{Cl}$ blend were determined at the start of the experiment. Further tests were made on all media at 15 and $30 \mathrm{~d}$ to monitor the effects of the added $S$. One row of seedlings (seven plugs) was removed to provide the 15 - and 30-d media samples.

Emergence was recorded every evening from 11 to 22 Sept. using the 
"toothpick technique" as described for Expts. 1 and 2. Seedlings were thinned to the one strongest plant in each cell on 29 Sept., and a postthinning stand count was done to determine how many flat cells in the data areas were empty. Seedlings were fertilized on 2 Oct. using $1 \mathrm{oz}$ of soluble fertilizer $(20 \mathrm{~N}-8.7 \mathrm{P}-16.6 \mathrm{~K})$ in $2 \mathrm{gal}$ of water.

Plants were harvested on 9 and 10 Oct. Data were taken as described for Expts. 1 and 2, except that eight random seedlings were sampled per treatment per replication.

Expt. 4. Age of the peat-lite medium was not noted when Expt. 3 was set up. After experimental results became evident, we investigated and discovered that the medium had been produced in 2010. The results of Expt. 3 thus led to questions about effects of age of the peat-lite medium and age of the compost. Therefore, a $3 \times 3$ factorial treatment design was created. Levels of peat-lite were PLl (the Redi-Earth produced in 2010 and used in Expt. 3), PL2 (a "new" batch of Redi-Earth produced in 2013), and PL3 (Metro Mix produced in 2013 , averaging $45 \%$ to $50 \%$ composted pine bark, plus vermiculite, Canadian sphagnum peatmoss, perlite, and dolomitic limestone; Sun Gro Horticulture). Peat-lite media were either used unblended, or blended with $20 \% \mathrm{Cl}$ (the aged 2012 compost used in Expt. 3) or 20\% C2 (a fresh batch of YWC obtained from the Norman Composting Facility on 12 Oct. 2013 and screened to 0.5 inch).

Experimental media were prepared on 31 Oct. 2013. Nine polystyrene flats were each divided by duct tape into three sections of six rows each to allow three media treatments per flat. The experiment was arranged in a randomized complete block design with three replications. Edge cells were not used for data, leaving 32 data cells per treatment per replication. Filled flats were watered to saturation. The following day, pelleted 'Genovese' basil seeds were planted following the same procedures as in the previous experiments. Flats were watered after seeding and placed in the greenhouse, where they continued to be watered daily. Temperature set points were $68 / 60{ }^{\circ} \mathrm{F}$ (day/night), but actual temperatures varied by at least $\pm 10^{\circ} \mathrm{F}$.

Emergence was recorded every evening from 9 to 22 Nov. using the "toothpick technique" as described for Expts. 1 and 2. Seedlings were thinned to the one strongest plant in each cell on $8 \mathrm{Dec}$., and a postthinning stand count was done to determine how many flat cells in the data areas were empty. Seedlings were fertilized on 15 and $22 \mathrm{Dec}$. using $\mathrm{l} \mathrm{oz}$ of soluble fertilizer $(20 \mathrm{~N}-8.7 \mathrm{P}-16.6 \mathrm{~K})$ in $2 \mathrm{gal}$ of water each time.

Plants were harvested on 11 and 12 Jan. 2014. Data were taken as described for Expt. 3, with eight random seedlings sampled per treatment per replication.

Media characteristics. Analyses were performed on all experimental media at the start of each experiment by the Soil and Plant Tissue Testing Laboratory, West Experiment Station, Univ. of Massachusetts, Amherst. Protocols were from "Test Method for the Examination of Composting and Compost" (U.S. Composting Council, Bethesda, MD). Variables analyzed may be determined by examining Tables $1,2,5$, and 6 .

Statistical analysis. Mean time to emergence was calculated as $\sum$ (days to emergence) (no. of seedlings emerged on that day)/total no. of seedlings emerged (Gerson and Honma, 1978). Data were evaluated with analysis of variance procedures (PROC MIXED) using SAS software (version 9.4; SAS Institute, Cary, NC) assuming a randomized complete block model. Linear and quadratic orthogonal polynomial contrasts were calculated where appropriate. If the test of treatments was determined to be significant $(P \leq 0.05)$, separation was done using protected pairwise comparisons on least square means.

\section{Results and discussion}

For the 2012 experiments, blending compost with the $100 \%$ peat-lite medium altered media physical and chemical characteristics (Tables $\mathrm{I}$ and $2)$. The compost was alkaline ( $\mathrm{pH} 8.3$ ). Compost electrical conductivity (EC) was not especially high, and the blends containing $<50 \%$ compost had EC values of $<\mathrm{l} \mathrm{dS} \cdot \mathrm{m}^{-1}$. Ozores-Hampton et al. (1999) noted that compost should have an EC of $\leq 3.5 \mathrm{dS} \cdot \mathrm{m}^{-1}$ when used for transplant production. The compost was relatively high in total nitrogen $(\mathrm{N})$ but low in nitrate$\mathrm{N}$ and ammonium- $\mathrm{N}$. However, the carbon:nitrogen $(\mathrm{C}: \mathrm{N})$ ratio of 10.8:1 was within the range (10:1 to $15: 1)$ given by Sullivan and Miller (2001) for stable soil organic matter. Other measured elements (Table 2) generally were in the expected range for a useable compost (Allen and Kariuki, 2014; Bugbee and Frink, 1989).

Blending compost with peat-lite did not consistently affect basil seedling establishment in the $2012 \mathrm{ex}-$ periments, although germination was suppressed with $100 \%$ compost (Table 3). However, negative effects on seedling height and weight occurred even with just $20 \%$ compost in the medium (Table 4). Responses

Table 1. Some physical and chemical characteristics of media used in the 2012 basil transplant production experiments (Expts. 1 and 2).

\begin{tabular}{|c|c|c|c|c|c|c|c|c|}
\hline \multirow[b]{2}{*}{ Treatments $^{\mathrm{z}}$} & \multirow[b]{2}{*}{$\begin{array}{c}\text { Moist bulk } \\
\text { density }\left(\mathrm{g} \cdot \mathrm{cm}^{-3}\right)^{\mathrm{y}} \\
\end{array}$} & \multirow[b]{2}{*}{$\mathrm{pH}$} & \multirow[b]{2}{*}{$\begin{array}{c}\mathrm{EC} \\
\left(\mathrm{dS} \cdot \mathrm{m}^{-1}\right)^{\mathrm{y}}\end{array}$} & \multirow[b]{2}{*}{$\begin{array}{l}\text { Carbon } \\
(\mathrm{C})(\%)\end{array}$} & \multicolumn{3}{|c|}{ Nitrogen $(\mathrm{N})$} & \multirow[b]{2}{*}{$\begin{array}{l}\mathrm{C}: \mathrm{N} \\
\text { ratio }\end{array}$} \\
\hline & & & & & $\begin{array}{c}\text { Nitrate } \\
\left(\mathrm{mg} \cdot \mathrm{kg}^{-1}\right)^{\mathrm{y}}\end{array}$ & $\begin{array}{c}\text { Ammonium } \\
\left(\mathrm{mg} \cdot \mathrm{kg}^{-1}\right)\end{array}$ & $\begin{array}{c}\text { Total } \\
(\%)\end{array}$ & \\
\hline $100 \%$ peat-lite (PLO) & 0.21 & 6.4 & 0.31 & 16.3 & 92 & 37 & 0.43 & 38.2 \\
\hline $60 \%$ PL0, $40 \%$ C0 & 0.36 & 7.8 & 0.86 & 20.8 & 12 & 12 & 1.19 & 17.5 \\
\hline $40 \%$ PL0, $60 \%$ C0 & 0.47 & 7.7 & 1.82 & 22.0 & 8 & 8 & 1.69 & 13.0 \\
\hline
\end{tabular}

${ }^{2}$ Treatments were $100 \%$ peat-lite [PL0 (Redi-Earth; Sun Gro Horticulture, Agawam, MA)], or this medium mixed with yard waste compost (C0, aged about $4 \mathrm{~d}$ after being obtained) at $80 \%: 20 \%, 60 \%: 40 \%, 40 \%: 60 \%$, and $20 \%: 80 \%$ by volume, or $100 \%$ compost.

${ }^{\mathrm{y}} 1 \mathrm{~g} \cdot \mathrm{cm}^{-3}=62.4274 \mathrm{lb} / \mathrm{ft}^{3}, 1 \mathrm{dS} \cdot \mathrm{m}^{-1}=1 \mathrm{mmho} / \mathrm{cm}, 1 \mathrm{mg} \cdot \mathrm{kg}^{-1}=1 \mathrm{ppm}$. 
Table 2. Elemental concentrations of media used in the 2012 basil transplant production experiments (Expts. 1 and 2 ).

\begin{tabular}{|c|c|c|c|c|c|c|c|c|}
\hline \multirow[b]{2}{*}{ Treatments $^{\mathrm{z}}$} & \multicolumn{8}{|c|}{ Elemental concn $\left(\mathrm{mg} \cdot \mathrm{kg}^{-1}\right)^{\mathrm{y}}$} \\
\hline & $\mathbf{P}$ & $\mathbf{K}$ & $\mathrm{Ca}$ & $\mathrm{Mg}$ & $\mathrm{Fe}$ & $\mathrm{Zn}$ & $\mathbf{C u}$ & B \\
\hline $100 \%$ peat-lite (PLO) & 137 & 894 & 4201 & 2759 & $\mathrm{BDL}^{\mathrm{x}}$ & 2.0 & 2.3 & 0.5 \\
\hline $60 \%$ PLO, $40 \%$ C0 & 614 & 3294 & 12161 & 2571 & 0.4 & 3.3 & 1.9 & 6.1 \\
\hline $40 \%$ PL0, $60 \%$ C0 & 644 & 3932 & 11528 & 2030 & 3.0 & 4.4 & 8.6 & 6.3 \\
\hline $20 \%$ PL0, $80 \%$ C0 & 634 & 5542 & 12207 & 1910 & BDL & 3.8 & 6.5 & 7.0 \\
\hline
\end{tabular}

${ }^{2}$ Treatments were 100\% peat-lite [PL0 (Redi-Earth; Sun Gro Horticulture, Agawam, MA)], or this medium mixed with yard waste compost (C0, aged about $4 \mathrm{~d}$ after being obtained) at $80 \%: 20 \%, 60 \%: 40 \%, 40 \%: 60 \%$, and $20 \%: 80 \%$ by volume, or $100 \%$ compost.

y Phosphorus $(\mathrm{P})$, potassium $(\mathrm{K})$, calcium $(\mathrm{Ca})$, magnesium $(\mathrm{Mg})$, iron $(\mathrm{Fe})$, zinc $(\mathrm{Zn})$, copper $(\mathrm{Cu})$, boron $(\mathrm{B}) ; \mathrm{l} \mathrm{mg} \cdot \mathrm{kg}^{-1}=1 \mathrm{ppm}$.

Below detectable levels.

Table 3. Effects of compost amendments to a peat-lite medium on basil seedling establishment in plug trays in a greenhouse, Expts. 1 and 2, 2012.

\begin{tabular}{|c|c|c|c|c|c|c|}
\hline \multirow[b]{2}{*}{ Treatments $^{\mathrm{z}}$} & \multicolumn{2}{|c|}{ Mean time to emergence (d) } & \multicolumn{2}{|c|}{ Emergence (\%) } & \multicolumn{2}{|c|}{ Stand after thinning (no. plants) } \\
\hline & Expt. 1 & Expt. 2 & Expt. 1 & Expt. 2 & Expt. 1 & Expt. 2 \\
\hline $100 \%$ peat-lite (PLO) & 4.5 & 6.4 & 80 & 79 & 54 & 54 \\
\hline $60 \%$ PLO, $40 \%$ C0 & 4.5 & 6.8 & 77 & 86 & 53 & 54 \\
\hline $40 \%$ PL0, $60 \%$ C0 & 4.6 & $7.6^{* *}$ & 83 & 76 & 55 & 52 \\
\hline $20 \%$ PLO, $80 \%$ C0 & 4.8 & $8.1 * *$ & 80 & 74 & 53 & 53 \\
\hline $100 \% 2012$ compost $(\mathrm{C} 0)$ & \multicolumn{6}{|c|}{$P>\mathrm{F}$ for contrasts } \\
\hline Linear & $<0.001$ & $<0.001$ & 0.832 & 0.002 & 0.664 & $<0.001$ \\
\hline Quadratic & 0.005 & 0.871 & 0.918 & 0.198 & 0.666 & 0.079 \\
\hline Lack of fit & 0.527 & 0.284 & 0.322 & 0.146 & 0.234 & 0.491 \\
\hline
\end{tabular}

${ }^{2}$ Treatments were $100 \%$ peat-lite [PL0 (Redi-Earth; Sun Gro Horticulture, Agawam, MA)], or this medium mixed with yard waste compost (C0, aged about $4 \mathrm{~d}$ after being obtained) at $80 \%: 20 \%, 60 \%: 40 \%, 40 \%: 60 \%$, and $20 \%: 80 \%$ by volume, or $100 \%$ compost. Within columns, means differ from the control ( $100 \% \mathrm{PL}$ ) at $P \leq 0.05$ (*) or $P \leq 0.01$ $(* *)$, or do not differ from the control (no symbol) using protected pairwise comparisons on least square means.

${ }^{y}$ Number of plants out of a potential maximum of 56 plants.

Table 4. Effects of compost amendments to a peat-lite medium on quality of basil seedlings in plug trays in a greenhouse, Expts. 1 and 2, 2012.

\begin{tabular}{|c|c|c|c|c|c|c|}
\hline \multirow[b]{3}{*}{ Treatments $^{\mathrm{z}}$} & \multirow{2}{*}{\multicolumn{2}{|c|}{$\mathrm{Ht}(\mathrm{cm})^{\mathrm{y}}$}} & \multicolumn{4}{|c|}{ Dry wt } \\
\hline & & & \multicolumn{2}{|c|}{ Mean $(\mathrm{mg})^{y}$} & \multicolumn{2}{|c|}{$(\%)$} \\
\hline & Expt. 1 & Expt. 2 & Expt. 1 & Expt. 2 & Expt. 1 & Expt. 2 \\
\hline $80 \%$ PL0, $20 \%$ C0 & $3.8 * *$ & $2.9 * *$ & $58 * *$ & $44^{* *}$ & $10.8^{* *}$ & 10.2 \\
\hline $60 \%$ PL0, $40 \%$ C0 & $2.4^{* *}$ & $2.3 * *$ & $34 * *$ & $27 * *$ & $12.8 * *$ & 11.2 ** \\
\hline $40 \%$ PL0, $60 \%$ C0 & $1.7 * *$ & $1.5 * *$ & $20 * *$ & $12 * *$ & $13.8 * *$ & 13.0 ** \\
\hline & \multicolumn{6}{|c|}{$P>\mathrm{F}$ for contrasts } \\
\hline Linear & $<0.001$ & $<0.001$ & $<0.001$ & $<0.001$ & $<0.001$ & $<0.001$ \\
\hline Quadratic & $<0.001$ & $<0.001$ & $<0.001$ & $<0.001$ & 0.099 & 0.024 \\
\hline Lack of fit & $<0.001$ & 0.014 & $<0.001$ & 0.012 & 0.024 & 0.575 \\
\hline
\end{tabular}

${ }^{2}$ Treatments were $100 \%$ peat-lite [PL0 (Redi-Earth; Sun Gro Horticulture, Agawam, MA)], or this medium mixed with yard waste compost (C0, aged about $4 \mathrm{~d}$ after being obtained) at $80 \%: 20 \%, 60 \%: 40 \%, 40 \%: 60 \%$, and $20 \%: 80 \%$ by volume, or $100 \%$ compost. Within columns, means differ from the control ( $100 \%$ PL) at $P \leq 0.01$ ( **) or do not differ from the control (no symbol) using protected pairwise comparisons on least square means.

${ }^{\mathrm{y}} \mathrm{l} \mathrm{cm}=0.3937 \mathrm{inch}, 1 \mathrm{mg}=3.5274 \times 10^{-5} \mathrm{oz}$

usually did not fit a simple quadratic curve. Instead, there was a distinct decline in seedling height and dry weight between 100\% PL0 and 80\% PL0:20\% $\mathrm{C} 0$, followed by smaller decreases as the percentage of compost increased in the blends. Percent dry weight, in contrast, tended to increase as the percentage of compost increased in the blends. Seedlings grown in $80 \%$ PL0:20\% C0 appeared normal, even though they were less than half the height and weight of control seedlings. Michel and Doohan (2003) noted that residual amounts of herbicides in compost may cause damage to seedlings.
No signs of chlorosis or distorted growth were apparent, so herbicide injury was not suspected as a factor in this investigation. The alkalinity of the media could have adversely affected seedling growth; hence, in a later experiment, we investigated the benefits of acidifying the medium with $S$. 
One can observe changes in the 2012 compost after aging by comparing data in Tables 1 and 2 with data in Tables 5 and 6 . Variables that were essentially unchanged included moist bulk density, percent $\mathrm{C}$, percent $\mathrm{N}$, and $\mathrm{C}: \mathrm{N}$ ratio. The aged 2012 compost $(\mathrm{Cl})$ had decreased in $\mathrm{pH}$ (from 8.3 to 7.2 ), increased in EC (from 2.84 to $7.21 \mathrm{dS} \cdot \mathrm{m}^{-1}$ ), and most dramatically, increased in nitrate $\mathrm{N}$ (from 5 to $1845 \mathrm{mg} \cdot \mathrm{kg}^{-1}$ ) compared with the original compost $(\mathrm{C} 0)$.

As already stated, age of the peat-lite medium was not noted when Expt. 3 was set up. Thus, we were surprised that the $100 \% \mathrm{PLl}$ treatment was detrimental to the basil seedlings in Expt. 3, as evidenced by increased days to emergence, shorter height, and very low dry weight relative to seedlings grown in $80 \% \mathrm{PLl}: 20 \%$ Cl blends (Table 7). Further, it was clear that the aged 2012 compost (Cl) was not inhibitory to basil seedling growth when blended at $20 \%$ with the PLl. Media analyses (Tables 5 and 6) did not show anything unusual about PLl. Further media analyses performed in a Sun Gro Horticulture laboratory (T. Cavins, personal communication) confirmed this (data not presented) but also indicated that the PLl medium was highly resistant to wetting. It was found that the PLl had been produced in 2010, and the conclusion was that the wetting agent had degraded over time.
Baseline $\mathrm{pH}$ values as measured in our laboratory for $100 \%$ PL1, 100\% $\mathrm{Cl}$, and the $80 \% \mathrm{PLl}: 20 \% \mathrm{Cl}$ blend were $5.25,7.63$, and 6.54 , respectively. Data in Table 7 suggest that without added $S$, the media became more alkaline during seedling production. Treatments with S lowered the $\mathrm{pH}$ of the $80 \% \mathrm{PLI}: 20 \% \mathrm{Cl}$ blend, especially at $30 \mathrm{~d}$ after seeding (Table 7). Tittarelli et al. (2009) also successfully used elemental $S$ to lower the $\mathrm{pH}$ of media containing greenwaste compost. However, in our study, basil seedlings grown in the unamended 80\% PLl:20\% Cl blend and blends with added $S$ showed no differences in measured growth variables. Although this experiment was

Table 5. Some physical and chemical characteristics of media used in the 2013 and 2014 basil transplant production experiments (Expts. 3 and 4 ).

\begin{tabular}{|c|c|c|c|c|c|c|c|c|}
\hline \multirow[b]{2}{*}{ Treatments $^{\mathrm{z}}$} & \multirow{2}{*}{$\begin{array}{l}\text { Moist bulk } \\
\text { density } \\
\left(\mathrm{g} \cdot \mathrm{cm}^{-3}\right)^{\mathrm{y}}\end{array}$} & \multirow[b]{2}{*}{$\mathrm{pH}$} & \multirow[b]{2}{*}{$\begin{array}{c}E C \\
\left(\mathrm{dS} \cdot \mathrm{m}^{-1}\right)^{\mathrm{y}}\end{array}$} & \multirow[b]{2}{*}{$\begin{array}{l}\text { Carbon } \\
(\mathrm{C})(\%)\end{array}$} & \multicolumn{3}{|c|}{ Nitrogen $(\mathbf{N})$} & \multirow[b]{2}{*}{$\begin{array}{l}\mathrm{C}: \mathrm{N} \\
\text { ratio } \\
\end{array}$} \\
\hline & & & & & $\begin{array}{c}\text { Nitrate } \\
\left(\mathrm{mg} \cdot \mathrm{kg}^{-1}\right)^{y}\end{array}$ & $\begin{array}{c}\text { Ammonium } \\
\left(\mathrm{mg} \cdot \mathrm{kg}^{-1}\right)\end{array}$ & $\begin{array}{c}\text { Total } \\
(\%)\end{array}$ & \\
\hline $100 \%$ peat-lite 1 (PLl) & 0.18 & 6.6 & 0.47 & 20.7 & 30 & 30 & 0.44 & 47.5 \\
\hline $100 \%$ peat-lite 2 (PL2) & 0.21 & 6.4 & 0.42 & 17.7 & 142 & 28 & 0.49 & 36.1 \\
\hline $100 \%$ peat-lite 3 (PL3) & 0.31 & 6.3 & 0.73 & 34.7 & 45 & 22 & 0.70 & 49.4 \\
\hline $100 \%$ aged 2012 compost $(\mathrm{Cl})$ & 0.56 & 7.2 & 7.21 & 21.8 & 1845 & 11 & 2.04 & 10.7 \\
\hline $80 \%$ PL2, $20 \% \mathrm{Cl}$ & 0.25 & 6.7 & 1.45 & 20.0 & 696 & 11 & 1.02 & 19.5 \\
\hline $80 \%$ PL3, 20\% Cl & 0.29 & 6.5 & 1.74 & 31.5 & 522 & 10 & 1.15 & 27.4 \\
\hline $80 \% \mathrm{PLl}, 20 \% \mathrm{C} 2$ & 0.22 & 6.6 & 0.81 & 22.1 & 39 & 13 & 0.96 & 23.1 \\
\hline $80 \%$ PL2, $20 \%$ C2 & 0.25 & 6.7 & 0.64 & 20.0 & 105 & 12 & 0.91 & 22.0 \\
\hline $80 \%$ PL3, $20 \%$ C2 & 0.34 & 6.7 & 0.97 & 18.2 & 33 & 7 & 0.81 & 22.5 \\
\hline
\end{tabular}

Table 6. Elemental concentrations of media used in the 2013 and 2104 basil transplant production experiments (Expts. 3 and 4 ).

\begin{tabular}{|c|c|c|c|c|c|c|c|c|}
\hline \multirow[b]{2}{*}{ Treatments $^{\mathrm{z}}$} & \multicolumn{8}{|c|}{ Elemental concn $\left(\mathrm{mg} \cdot \mathrm{kg}^{-1}\right)^{\mathrm{y}}$} \\
\hline & $\mathbf{P}$ & $\mathbf{K}$ & $\mathrm{Ca}$ & $\mathrm{Mg}$ & $\mathrm{Fe}$ & Zn & $\mathrm{Cu}$ & B \\
\hline $100 \%$ peat-lite $1(\mathrm{PLl})$ & 63 & 1302 & 5118 & 5372 & 36.8 & 3.3 & 1.3 & 0.7 \\
\hline $100 \%$ peat-lite 3 (PL3) & 114 & 889 & 5396 & 2441 & 1.5 & 3.7 & 0.3 & 0.7 \\
\hline $100 \%$ aged 2012 compost $(\mathrm{Cl})$ & 726 & 7335 & 16949 & 2220 & 6.5 & 4.4 & 0.6 & 9.4 \\
\hline $100 \%$ new 2013 compost (C2) & 608 & 5836 & 14457 & 1533 & 4.3 & 3.0 & 0.4 & 8.7 \\
\hline $80 \%$ PL3, 20\% Cl & 368 & 2456 & 10290 & 2483 & 4.4 & 3.9 & 0.5 & 3.6 \\
\hline $80 \% \mathrm{PLl}, 20 \% \mathrm{C} 2$ & 338 & 2221 & 9859 & 4463 & 23.8 & 3.3 & 1.0 & 3.7 \\
\hline $80 \%$ PL2, $20 \%$ C2 & 680 & 1562 & 9400 & 2634 & 7.7 & 2.1 & 0.5 & 3.0 \\
\hline $80 \%$ PL3, 20\% C2 & 249 & 1653 & 8003 & 1619 & 3.1 & $-^{\mathrm{x}}$ & 1.3 & 2.5 \\
\hline
\end{tabular}

${ }^{2} \mathrm{PLl}=100 \%$ Redi-Earth (Sun Gro Horticulture, Agawam, MA) produced in 2010 and not the same batch as was used in 2012 ; PL2 = a "new" batch of Redi-Earth produced in 2013; PL3 = Metro Mix (Sun Gro Horticulture) produced in 2013; Cl = the same yard waste compost used in 2012 (designated C0 in Expts. 1 and 2 ) but now aged about 17 mo. after being obtained; C2 = a "new" batch of yard waste compost, aged about $19 \mathrm{~d}$ after being obtained. Expt. 3 used $100 \%$ PL1 and also blended $80 \%$ PL1, 20\% C1. All treatments except $100 \% \mathrm{Cl}$ and $100 \% \mathrm{C} 2$ were used in Expt. 4.

'Phosphorus $(\mathrm{P})$, potassium $(\mathrm{K})$, calcium $(\mathrm{Ca})$, magnesium $(\mathrm{Mg})$, iron $(\mathrm{Fe})$, zinc $(\mathrm{Zn})$, copper $(\mathrm{Cu})$, boron $(\mathrm{B}) ; 1 \mathrm{mg} \cdot \mathrm{kg}^{-1}=1 \mathrm{ppm}$.

${ }^{x}$ Estimated value $=2.5$. 
Table 7. Effects of compost and sulfur amendments to a peat-lite medium on seedling establishment and quality of basil seedlings in plug trays in a greenhouse, and on medium $\mathrm{pH}$ (Expt. 3, 2013).

\begin{tabular}{|c|c|c|c|c|c|c|c|c|}
\hline \multirow[b]{2}{*}{ Treatments $^{\mathrm{z}}$} & \multirow[b]{2}{*}{$\begin{array}{l}\text { Mean time to } \\
\text { emergence }(\mathrm{d})\end{array}$} & \multirow[b]{2}{*}{$\begin{array}{c}\text { Emergence } \\
(\%)\end{array}$} & \multirow{2}{*}{$\begin{array}{l}\text { Stand after } \\
\text { thinning } \\
\text { (no. plants) }^{\mathrm{y}}\end{array}$} & \multirow[b]{2}{*}{$\begin{array}{l}\mathrm{Ht} \\
(\mathrm{cm})^{\mathrm{x}}\end{array}$} & \multicolumn{2}{|c|}{ Dry wt } & \multirow[b]{2}{*}{$\begin{array}{l}\mathrm{pH} \text { at } \\
15 \text { DAS }^{\mathrm{x}}\end{array}$} & \multirow[b]{2}{*}{$\begin{array}{c}\text { pH at } \\
30 \text { DAS }^{x}\end{array}$} \\
\hline & & & & & $\begin{array}{l}\text { Mean } \\
(\mathrm{mg})^{\mathrm{x}}\end{array}$ & $(\%)$ & & \\
\hline $100 \%$ peat-lite 1 (PLl) & $4.7 \mathrm{a}^{\mathrm{w}}$ & 85 & 48 & $1.8 \mathrm{~b}$ & $5 \mathrm{~b}$ & 7.7 & $6.1 \mathrm{c}$ & $7.3 \mathrm{~b}$ \\
\hline $80 \% \mathrm{PLl}, 20 \% \mathrm{Cl}$ & $3.7 \mathrm{~b}$ & 85 & 48 & $4.8 \mathrm{a}$ & $49 \mathrm{a}$ & 8.0 & $7.6 \mathrm{a}$ & $7.9 \mathrm{a}$ \\
\hline $80 \% \mathrm{PLl}, 20 \% \mathrm{Cl}, \mathrm{Sl}$ & $3.4 \mathrm{~b}$ & 84 & 46 & $5.4 \mathrm{a}$ & $53 \mathrm{a}$ & 8.1 & $7.0 \mathrm{ab}$ & $7.3 \mathrm{~b}$ \\
\hline $80 \% \mathrm{PLl}, 20 \% \mathrm{Cl}, \mathrm{S} 2$ & $3.9 \mathrm{~b}$ & 84 & 47 & $5.0 \mathrm{a}$ & $50 \mathrm{a}$ & 7.9 & $6.4 \mathrm{bc}$ & $6.5 \mathrm{c}$ \\
\hline & \multicolumn{8}{|c|}{$P>\mathrm{F}$ for contrasts within sulfur rates $(\mathrm{S} 1, \mathrm{~S} 2, \mathrm{~S} 3)$} \\
\hline Linear & 0.300 & 0.700 & 0.777 & 0.188 & 0.099 & 0.842 & 0.020 & $<0.001$ \\
\hline Quadratic & 0.187 & 0.565 & 0.091 & 0.975 & 0.719 & 0.838 & 0.911 & 0.718 \\
\hline
\end{tabular}

Table 8. Baseline effects of three peat-lite media on seedling establishment and quality of basil seedlings in plug trays in a greenhouse (Expt. 4, 2013-14).

\begin{tabular}{|c|c|c|c|c|c|c|}
\hline \multirow[b]{2}{*}{ Treatments $^{\mathrm{z}}$} & \multirow[b]{2}{*}{$\begin{array}{l}\text { Mean time to } \\
\text { emergence }(d)\end{array}$} & \multirow[b]{2}{*}{$\begin{array}{c}\text { Emergence } \\
(\%)\end{array}$} & \multirow[b]{2}{*}{$\begin{array}{c}\text { Stand after } \\
\text { thinning (no. plants) }\end{array}$} & \multirow[b]{2}{*}{$\begin{array}{c}\mathrm{Ht} \\
(\mathrm{cm})^{\mathrm{x}}\end{array}$} & \multicolumn{2}{|c|}{ Dry wt } \\
\hline & & & & & $\begin{array}{l}\text { Mean } \\
(\mathrm{mg})^{\mathrm{x}}\end{array}$ & $(\%)$ \\
\hline $100 \%$ peat-lite $1(\mathrm{PLl})$ & $14.0 \mathrm{a}^{\mathrm{w}}$ & $57 \mathrm{~b}$ & $21 \mathrm{~b}$ & $0.8 \mathrm{~b}$ & $6 \mathrm{~b}$ & $12.5 \mathrm{a}$ \\
\hline $100 \%$ peat-lite 2 (PL2) & $12.1 \mathrm{a}$ & $77 \mathrm{a}$ & $31 \mathrm{a}$ & $1.3 \mathrm{a}$ & $20 \mathrm{a}$ & $11.3 \mathrm{a}$ \\
\hline $100 \%$ peat-lite 3 (PL3) & $12.0 \mathrm{a}$ & $76 \mathrm{a}$ & $30 \mathrm{a}$ & $1.6 \mathrm{a}$ & $26 \mathrm{a}$ & $9.8 \mathrm{a}$ \\
\hline
\end{tabular}

${ }^{2} \mathrm{PLl}=100 \%$ Redi-Earth (Sun Gro Horticulture, Agawam, MA) produced in 2010 and not the same batch as was used in 2012; PL2 = "new" batch of Redi-Earth produced in 2013; PL3 = Metro Mix (Sun Gro Horticulture) produced in 2013

${ }^{y}$ Number of plants out of a potential maximum of 32 plants.

${ }^{x} 1 \mathrm{~cm}=0.3937$ inch, $1 \mathrm{mg}=3.5274 \times 10^{-5} \mathrm{oz}$.

"Two means in the same column with the same letter do not differ at $P \leq 0.05$ using protected pairwise comparisons on least square means.

not designed to determine an optimum medium $\mathrm{pH}$ for basil transplant production, we can conclude that medium $\mathrm{pH}$ values from 5.7 to 7.9 had no significant effect on seedling production. These results indicated that $\mathrm{pH}$ changes could not explain the inhibited growth of basil seedlings in Expts. 1 and 2, at least for blends containing $\leq 60 \%$ compost. However, high $\mathrm{pH}(8.3)$ may partially explain the inhibition of seedling emergence observed with 100\% C0 in Expts. 1 and 2.

Baseline data for Expt. 4 (Table 8) confirm that the unamended PLl was inhibitory to basil seedling establishment and development. Stand after thinning in PLl was only $66 \%$ of the possible maximum of one plant per flat cell, due to poor germination and death of some young seedlings. In contrast, the two "fresh" peat-lite media (PL2 and PL3) were not inhibitory to germination and were similar to each other in effects on seedling establishment (Table 8), even though their physical and chemical characteristics sometimes differed (Tables 5 and 6).
Effects of compost amendments in Expt. 4 occurred primarily with PLl. The addition of aged compost $(\mathrm{Cl})$ affected all seedling responses positively compared with the unamended PLl, except for percent dry weight (Table 9). The new batch of compost (C2) improved only percent emergence and stand after thinning compared with the unamended PLl (Table 9). Effects of compost amendments with PL2 and PL3 were limited to Cl, and occurred primarily as increased seedling height compared with the unamended PL2 and PL3 (Table 9). We cannot conclude that a $20 \%$ replacement rate is ideal for basil transplant production. However, a blend of $80 \%$ PL2 or $80 \%$ PL3 with $20 \%$ compost produced similar $(\mathrm{C} 2)$ or somewhat better $(\mathrm{Cl})$ results than were obtained with the unamended peat-lite.

It is of interest to compare the differing responses to the $2012 \mathrm{com}$ post while it was fresh $(\mathrm{C} 0$ in Expts. 1 and 2) vs. a fresh batch of compost from the same facility obtained in 2013 (i.e., C2) in Expt. 4. Basil seedlings were smaller overall in Expt.
4 than in Expt. 1 because Expt. 4 took place under winter conditions. However, in Expt. 4, seedlings grown in $80 \%$ PL2 or $80 \%$ PL3 blended with $20 \%$ C2 were similar in height and dry weight to those produced in $100 \%$ PL2 or $100 \%$ PL3 (Table 9). In contrast, seedlings in Expts. 1 and 2 grown in $80 \%$ PL0 blended with $20 \%$ $\mathrm{C} 0$ were much shorter and lighter in weight than seedlings produced in $100 \%$ PL0 (Table 6). With comparison of results in Tables 1 and 2 with results in Tables 5 and 6 , two primary differences stand out: the $\mathrm{pH}$ of $\mathrm{C} 2$ was still alkaline (7.8) but less than the $\mathrm{pH}$ of $\mathrm{CO}(8.3)$, and nitrate $\mathrm{N}$ of C2 $\left(58 \mathrm{mg} \cdot \mathrm{kg}^{-1}\right)$ was much higher than that of C0 $\left(5 \mathrm{mg} \cdot \mathrm{kg}^{-1}\right)$. When considering the results of the four experiments, we believe that the main reason the $\mathrm{C} 0$ compost was inhibitory was that mineralization was slow or immobilization occurred, causing a lack of plant-available $\mathrm{N}$, especially nitrate. Burger et al. (1997) noted that some composted green wastes showed net $\mathrm{N}$ immobilization despite low $(<12)$ C:N ratios. Others (Barker and 
Table 9. Simple effects of compost amendments to three peat-lite media on seedling establishment and quality of basil seedlings in plug trays in a greenhouse (Expt. 4, 2013-14).

\begin{tabular}{|c|c|c|c|c|c|c|}
\hline \multirow[b]{2}{*}{ Treatments $^{\mathrm{z}}$} & \multirow[b]{2}{*}{$\begin{array}{l}\text { Mean time to } \\
\text { emergence }(d)\end{array}$} & \multirow[b]{2}{*}{$\begin{array}{c}\text { Emergence } \\
(\%)\end{array}$} & \multirow[b]{2}{*}{$\begin{array}{c}\text { Stand after } \\
\text { thinning (no. plants) }\end{array}$} & \multirow[b]{2}{*}{$\begin{array}{c}\mathrm{Ht} \\
(\mathrm{cm})^{\mathrm{x}}\end{array}$} & \multicolumn{2}{|c|}{ Dry wt } \\
\hline & & & & & $\begin{array}{l}\text { Mean } \\
(\mathrm{mg})^{\mathrm{x}}\end{array}$ & $(\%)$ \\
\hline $100 \%$ peat-lite 1 (PLl) & $14.0 \mathrm{a}^{\mathrm{w}}$ & $57 \mathrm{~b}$ & $21 \mathrm{~b}$ & $0.8 \mathrm{~b}$ & $6 a$ & $12.5 \mathrm{ab}$ \\
\hline $80 \% \mathrm{PLl}, 20 \% \mathrm{Cl}$ & $11.3 \mathrm{~b}$ & 81 a & $31 \mathrm{a}$ & $1.3 \mathrm{a}$ & $14 \mathrm{a}$ & $10.0 \mathrm{~b}$ \\
\hline $80 \%$ PL1, 20\% C2 & $12.1 \mathrm{ab}$ & $83 \mathrm{a}$ & 31 a & $0.9 \mathrm{~b}$ & $9 \mathrm{a}$ & $14.4 \mathrm{a}$ \\
\hline $100 \%$ peat-lite 2 (PL2) & $12.1 \mathrm{a}$ & $77 \mathrm{a}$ & $31 \mathrm{a}$ & $1.3 \mathrm{~b}$ & $20 \mathrm{ab}$ & $11.3 \mathrm{a}$ \\
\hline 100\% peat-lite 3 (PL3) & $12.0 \mathrm{a}$ & $76 \mathrm{a}$ & $30 \mathrm{a}$ & $1.6 \mathrm{~b}$ & $26 \mathrm{~b}$ & $9.8 \mathrm{a}$ \\
\hline $80 \%$ PL3, $20 \% \mathrm{Cl}$ & $12.0 \mathrm{a}$ & $77 \mathrm{a}$ & $31 \mathrm{a}$ & $2.1 \mathrm{a}$ & $43 \mathrm{a}$ & $9.8 \mathrm{a}$ \\
\hline $80 \%$ PL3, $20 \%$ C2 & $12.2 \mathrm{a}$ & $77 \mathrm{a}$ & $30 \mathrm{a}$ & $1.5 \mathrm{~b}$ & $27 \mathrm{~b}$ & $10.6 \mathrm{a}$ \\
\hline
\end{tabular}

${ }^{2} \mathrm{PL1}=100 \%$ Redi-Earth (Sun Gro Horticulture, Agawam, MA) produced in 2010 and not the same batch as was used in $2012 ;$ PL2 = a "new" batch of Redi-Earth produced in 2013; PL3 = Metro Mix (Sun Gro Horticulture) produced in 2013; Cl = the same yard waste compost used in 2012 (designated C0 in Expts. 1 and 2 ) but now aged about 17 mo. after being obtained; $\mathrm{C} 2$ = a "new" batch of yard waste compost, aged about $19 \mathrm{~d}$ after being obtained.

${ }^{y}$ Number of plants out of a potential maximum of 32 plants.

${ }^{\mathrm{x}} \mathrm{l} \mathrm{cm}=0.3937 \mathrm{inch}, 1 \mathrm{mg}=3.5274 \times 10^{-5} \mathrm{oz}$.

wTwo means in the same column within the same value of peat-lite medium with the same letter do not differ at $P \leq 0.05$ using protected pairwise comparisons on least square means.

Bryson, 2006; Clark and Cavigelli, 2005; O'Brien and Barker, 1996) observed limited shoot growth in test crops grown with composts characterized by low $\mathrm{N}$ content or net $\mathrm{N}$ immobilization.

It is essential for growers to understand the composition of the media at hand when producing basil transplants. Expiration dates should be noted on peat-lite media. Although fresh (no more than 1 year old) peat-lite media are recommended, our work suggests that blending in mature YWC at $20 \%$ by volume may restore utility to older batches of peat-lite media in which the wetting agent has degraded. Yard waste compost can be a viable substitute for $20 \%$ of a peat-lite mix in basil transplant production. However, growers should ensure that the compost has been received from a reputable source and is mature, with plenty of plantavailable $\mathrm{N}$. We agree with the recommendation given by Hartz et al. (1996) that standardized evaluation procedures are needed to allow the end user to determine the appropriate uses for YWC.

\section{Literature cited}

Allen, T. and S. Kariuki. 2014. Interpreting your compost test results. 18 June 2014. <http://soiltest.umass.edu/sites/ soiltest.umass.edu/files/fact-sheets/ pdf/Compost_Jan2014.pdf>.

Barker, A.V. and G.M. Bryson. 2006. Comparisons of composts with low or high nutrient status for growth of plants in containers. Commun. Soil Sci. Plant Anal. 37:1303-1319.

Boodley, J.W. and R. Sheldrake, Jr. 1982. Cornell peat-lite mixes for commercial plant growing. Cornell Coop. Ext. Serv. Info. Bul. 43.

Bugbee, G.J. and C.R. Frink. 1989. Composted waste as a peat substitute in peatlite media. HortScience 24:625-627.

Burger, D.W., T.K. Hartz, and G.W. Forister. 1997. Composted green waste as a container medium amendment for the production of ornamental plants. HortScience 32:57-60.

Clark, S. and M. Cavigelli. 2005. Suitability of composts as potting media for production of organic vegetable transplants. Compost Sci. Util. 13:150-155.

De Lucia, B., L. Vecchietti, S. Rinaldi, C.M. Rivera, A. Trinchera, and E. Rea. 2013. Effect of peat-reduced and peatfree substrates on rosemary growth. J. Plant Nutr. 36:863-876.

Gerson, R. and S. Honma. 1978. Emergence response of the pepper at low soil temperature. Euphytica 27:151-156.

Goldstein, N. 2001. The composting industry in the United States: Past, present, and future, p. 3-16. In: P.J. Stoffella and B.A. Kahn (eds.). Compost utilization in horticultural cropping systems. Lewis Publishers, Boca Raton, FL.

Hartz, T.K., F.J. Costa, and W.L. Schrader. 1996. Suitability of composted green waste for horticultural uses. HortScience 31:961-964.

Herrera, E., N. Tremblay, B. Desroches, and A. Gosselin. 1997. Optimization of substrate and nutrient solution for organic cultivation of medicinal transplants in mul- ticell flats. J. Herbs Spices Med. Plants 4(4):69-82.

Michel, F.C., Jr. and D. Doohan. 2003. Clopyralid and other pesticides in composts. Ohio State Univ. Ext. Fact Sheet AEX-714-03.

O'Brien, T.A. and A.V. Barker. 1996. Growth of peppermint in compost. J. Herbs Spices Med. Plants 4(1):19-27.

Ozores-Hampton, M., C.S. Vavrina, and T.A. Obreza. 1999. Yard trimmingbiosolids compost: Possible alternative to sphagnum peat moss in tomato transplant production. Compost Sci. Util. 7:42-49.

Pitchay, D.S. and J.C. Diaz-Perez. 2008. Is it possible to produce healthy organic herbal plug seedlings through different proportions of organic materials? Acta Hort. 782:215-222.

Raviv, M. 2005. Production of high-quality composts for horticultural purposes: A mini-review. HortTechnology 15:52-57.

Reuveni, R., M. Raviv, A. Krasnovsky, L. Freiman, S. Medina, A. Bar, and D. Orion. 2002. Compost induces protection against Fusarium oxysporum in sweet basil. Crop Prot. 21:583-587.

Spiers, T.M. and G. Fietje. 2000. Green waste compost as a component in soilless growing media. Compost Sci. Util. 8:19-23.

Sterrett, S.B. 2001. Composts as horticultural substrates for vegetable transplant production, p. 227-240. In: P.J. Stoffella and B.A. Kahn (eds.). Compost utilization in horticultural cropping systems. Lewis Publishers, Boca Raton, FL.

Succop, C.E. and S.E. Newman. 2004. Organic fertilization of fresh market sweet basil in a greenhouse. HortTechnology 14:235-239. 
Sullivan, D.M. and R.O. Miller. 2001. Compost quality attributes, measurements, and variability, p. 95-120. In: P.J. Stoffella and B.A. Kahn (eds.). Compost utilization in horticultural cropping systems. Lewis Publishers, Boca Raton, FL.

Tittarelli, F., E. Rea, V. Verrastro, J.A. Pascual, S. Canali, F.G. Ceglie, A. Trinchera, and C.M. Rivera. 2009. Compost-based nursery substrates: Effect of peat substitution on organic melon seedlings. Compost Sci. Util. 17:220-228.

Treadwell, D.D., G.J. Hochmuth, R.C. Hochmuth, E.H. Simonne, L.L. Davis, W.L. Laughlin, Y. Li, T. Olczyk, R.K. Sprenkel, and L.S. Osborne. 2007.
Nutrient management in organic greenhouse herb production: Where are we now? HortTechnology 17:461-466.

Zheljazkov, V.D. and P.R. Warman. 2004. Source-separated municipal solid waste compost application to swiss chard and basil. J. Environ. Qual. 33:542-552. 